Vol. 1 No. 2 Agustus 2021, e-ISSN : 2777-0575 P-ISSN : 2777-0583

\title{
REPRESENTASI SEJARAH, BUDAYA, DAN EKONOMI MASYARAKAT JAWA BARAT DALAM NOVEL HINOMARU : KAJIAN NEW HISTORICISM
}

\author{
YULIANTI \\ SMAN 1 GARUT \\ Email : Yyulianti322@gmail.com
}

\begin{abstract}
ABSTRAK
Tujuan penelitian ini adalah untuk merepresentasikan (1) peristiwa sejarah, (2) budaya, dan (3) ekonomi dalam novel Hinomaru karya lis W. Kartadinata. Analisis data dilakukan dengan menggunakan teknik analisis isi (content analysis). Hasil kajian meliputi: (1) representasi sejarah Indonesia dalam novel Hinomaru karya Iis W. Kartadinata digambarkan dalam kewajiban masyarakat pribumi menghormati Dewi Amaterasu dan Kaisar Jepang, mundurnya Belanda oleh Jepang pada tanggal 8 Maret 1942, dan adanya eksploitasi seksual terhadap perempuan-perempuan Sunda oleh tentara Jepang; (2) representasi budaya dalam novel Hinomaru terlihat dari penggunaan partikel, kata-kata, panggilan, kiasan, tembang, pantun, dan permainan tradisional Sunda; dan (3) representasi ekonomi dalam novel Hinomaru mengenai jenis pekerjaan sebagian besar penduduk, kemiskinan, dan kelaparan yang diderita karena adanya kewajiban membayar pajak terhadap penjajah.
\end{abstract}

Kata kunci: representasi sejarah, novel Hinomaru, new historicism

\section{PENDAHULUAN}

Novel merupakan karya imajinatif yang memiliki alur yang panjang. Seperti yang diungkapkan oleh Nurgiyantoro (2007:22) bahwa sebuah novel memiliki keterkaitan yang erat dan menguntungkan di antara bagian-bagian dan unsur-unsurnya. Latar belakang peristiwa yang bisa diangkat menjadi sebuah novel sangat beragam. Salah satunya adalah latar belakang sejarah. Melalui bahasa, sejarah dapat dihubungkan dengan sastra. Karya sastra merupakan deretan karya yang menjadi bagian dari sejarah dan disusun secara kronologis (Wellek dan Warren, 1955:38). Sastra sangat berhubungan erat dengan sejarah dan kehidupan masyarakat sehingga sastra. Dari kedua hal tersebutlah, sastra mendapakan nyawa. Menurut Budianta (2006:2), melalui tindak verbal imajinasi kreatifnya, sastra ikut membangun, mengartikulasikan, dan mereproduksi konvensi, norma, dan nilai-nilai budaya. Sebagaimana yang diungkapkan oleh Ratna (2008:259) bahwa karya sastra juga seperti sejarah, sosiologo, antropologi, psikologi, dan lain-lain yang menceritakan tentang manusia dalam masyarakat.

Salah satu karya sastra yang berlatarkan sejarah adalah Hinomaru karya lis W. Kartadinata. Novel Hinomaru memiliki latar pada tahun 1942 di daerah Subang, Jawa Barat. Pada saat itu, Indonesia sedang mengalami peralihan penjajahan dari Belanda kepada Jepang, termasuk Jawa Barat. Harapan bahwa Jepang akan memberikan kehidupan yang lebih baik ternyata yang terjadi adalah sebaliknya. Kekejaman Jepang serta aturan-aturan yang harus diikuti pribumi mewarnai alur cerita setiap tokohnya terutama tokoh utama, Halisah.

Novel Hinomaru diterbitkan pada tahun 2017 dan belum pernah dikaji dengan menggunakan pendekatan apapun. Penulis tertarik untuk menganalisis novel tersebut menggunakan pendekatan yang menekankan keterkaitan antara teks sastra dengan teks nonsastra yang dinamakan dengan pendekatan new historicism. Peristiwa-peristiwa sejarah, budaya, dan ekonomi yang ditemukan dalam novel tersebut akan disandingkan dengan teks nonsastra yang berupa dokumen-dokumen seperti buku, jurnal ilmiah, teks sejarah, dan penunjang lainnya.

Menurut Budianta (2006:4) sejarah dalam sebuah karya sastra tidak hanya menjadi latar belakang tetapi merupakan susunan kisah kenyataan. Selanjutnya, tentang budaya, Budianta (2006:8) menyatakan karya sastra merupakan bagian dari produk budaya yang menjadi sarana eksperimentasi, variasi, dan improvisasi berbagai nilai budaya. Selain kedua hal tersebut, hal lainnya yang juga kuat dalam pendekatan new historicism adalah dimensi ekonomi. Fakta-fakta 
sejarah, budaya, serta ekonomi yang ditemukan dalam novel Hinomaru akan disandingkan dengan teks nonsastra sebagai penyeimbang.

Kajian sejenis pernah dilakukan oleh Fairuzul Mumtaz (2014) dengan judul "Membongkar Kubur Sugiarti Siswadi (Sebuah Kajian New Historicism)". Dalam kajian tersebut, Mumtaz menemukan fakta-fakta seperti adanya kelas buruh, petani partai, serta prajurit pada tatanan masyarakat ketika masa PKI. Selain itu, paralelitas yang ditemukan Mumtaz terfokus pada 3 hal yaitu, landreform, perempuan dan anak, partai dan cita-cita sosialis. Kajian lain dilakukan oleh Mimas Ardhianti (2016) dengan judul "Kajian New Historicism Novel Hatta: Aku Datang karena Sejarah Karya Sergius Sutanto". Fakta-fakta yang ditemukan dalam kajian ini adalah fakta sosial, politik dan ekonomi pada masa Indonesia dijajah oleh Belanda dan Jepang.

\section{METODE PENELITIAN}

Pada penelitian ini, metode yang digunakan adalah deskriptif analisis. Ratna (2009: 53) menjelaskan bahwa deskripsi analisis dilakukan dengan cara mendeskripsikan, menguraikan, sampai memberikan pemahaman dan penjelasan fakta-fakta. Sumber data dalam penelitian ini adalah teks novel Hinomaru karya Iis W. Kartadinata. Langkah-langkah yang dilakukan untuk menganalisis data adalah 1) membaca novel; 2) memberi tanda pada kalimat atau paragraph yang berhubungan dengan peristiwa sejarah, budaya, dan ekonomi; 3) menganalisis hasil temuan tentang peristiwa sejarah, budaya, dan ekonomi; dan 4) mendeskripsikan hasil temuan.

\section{HASIL DAN PEMBAHASAN}

\section{A. Representasi Peristiwa Sejarah dalam Novel Hinomaru}

Peristiwa sejarah dalam novel Hinomaru menjadi bagian penting dalam perjalanan alur cerita tokoh utama dan tokoh-tokoh lainnya. Kehidupan masyarakat Jawa Barat, khususnya daerah Subang, yang menjadi latar novel ini digambarkan dalam suasana peralihan penjajahan Belanda ke penjajahan Jepang. Peristiwa sejarah pertama yang ditemukan mengenai keharusan masyarakat pribumi menghormati Dewi Amaterasu dan Kaisar Jepang, Tenno Heika, seperti terlihat pada kutipan 01.

\section{Kutipan 01}

Hinomaru dikibarkan. Kimigayo dinyanyikan. Lapangan senyap. Semua orang membungkukkan badan ke arah kiri sinar matahari yang baru naik seperempat langit.

Itulah wujud kepatuhan bagi Tenno Heika, yaitu yang memberi hormat Dewi Amaterasu (Kartadinata, 2017: 1).

Kutipan 01 memperlihatkan ciri kekuasaan penjajahan Jepang di Indonesia, yakni mengibarkan bendera Hinomaru dan menyanyikan lagu kebangsaan Jepang, Kimigayo. Selain itu, digambarkan juga bahwa ketika penjajahan Jepang, masyarakat dipaksa untuk mengikuti kebiasaan negara Jepang untuk menghormati Dewi Amaterasu. Amaterasu Oomikami, Dewi Matahari, dalam budaya Jepang merupakan sebuah produk, konsekuensi, dan dampak dari kekuatan laki-laki dan perempuan sebagai pemimpin tertinggi dunia langit (Lawanda, 2008: 57) berikut.

Penyembahan terhadap Dewi Matahari tersebut diperkuat oleh kutipan 02 dan 03 seperti

\section{Kutipan 02}

Pagi itu, acara penyembahan kepada Dewi Matahari usai.

"Euleuh-euleuh, orang-orang semua menyembah Dewi Amaterasu, apa dia sudah jadi Pangeran?" bisik-bisik itu sesaat saja, karena yang berani mengoceh pun, seketika membungkam. Langkah-langkah serdadu beke (pendek) bermata sipit, dengan samurai berjurai ke tanah, hilir mudik mengatur barisan (Kartadinata, 2017: 59).

Kutipan 03 
"Apa maksud Nipong menyuruh semua murid untuk menyanyikan Kimigayo, harus mengibarkan Hinomaru, dan menghormati Kaisar Nipong, Tenno Heika. Dan itu terjadi setiap hari. ..." (Kartadinata, 2017: 51).

Dari kutipan 02 dan 03 dapat diketahui bahwa semua kalangan masyarakat diharuskan memberi penghormatan terhadap Dewi Amaterasu dan Kaisar Jepang dengan cara membungkuk atau menundukkan kepala ke arah Tokyo setiap pagi. Kegiatan tersebut dinamakan seikerei. Masyarakat, khususnya umat Islam, menentang peraturan tersebut karena dianggap syirik, seperti perbuatan menyembah berhala dan menyamakan Kaisar Jepang dengan tuhan (Oktorino, 2013: 53)

Selain kewajiban memberi hormat kepada Dewi Matahari dan Kaisar Jepang, peristiwa sejarah lainnya yang terlihat pada novel Hinomaru adalah peristiwa mundurnya Belanda oleh Jepang. Hal ini terlihat pada kutipan-kutipan berikut.

\section{Kutipan 04}

Ciwidey 1942

"Mak, tuan-tuan Walanda itu pergi ke mana? Mengapa tidak tampak lagi di kampung kita?"

"Ssstttt," ada nada ketakutan pada desis larangannya, "Jangan keras-keras, geulis!" (Kartadinata, 2017: 2).

\section{Kutipan 05}

Tak ada lagi sisa-sisa orang kulit putih pernah berkuasa. Bangunan stasiun, rel-rel kereta, jembatan-jembatan kokoh dari baja, kini tinggal peninggalannya. Sekarang tentara Nipong memegang kendali semuanya ... (Kartadinata, 2017: 47).

Kutipan 04 dan 05 menunjukkan bahwa masyarakan desa sudah tidak melihat tentara Belanda lalu lalang di jalanan desa. Hal ini sesuai dengan fakta menurut Ricklefs (2008: 401 402) bahwa tentara Belanda di Pulau Jawa telah menyerah kepada Jepang. Selama menjajah Indonesia, Belanda tidak mendapatkan serangan berarti dari Indonesia. Namun, ketika Jepang berhasil menyerang Pearl Harbour, Hongkong, Filipina, dan Malaysia, semua itu berubah. Tanggal 8 Maret 1941 menjadi masa-masa terakhir penjajahan Indonesia oleh Belanda.

Ketidakberdayaan Belanda melawan Jepang terlihat pada kutipan 06 dan 07 dalam novel seperti berikut.

\section{Kutipan 06}

Beredar kabar, kehidupan para penggede Belanda di Kota Bandung mulai kocar-kacir, setelah terdengar desas-desus tentara Jepang mendarat di Jawa, dipimpin oleh Letnan Jenderal Imamura. ...

Sekira setengah 7 malam, Letnan Jenderal H. Ter Poorten sebagai Panglima Tentara Hindia Belanda, menandatangani surat keterangan Belanda menyerah kepada Jepang sesuai tuntutan Letnan Jenderal Immamura. ... (Kartadinata, 2017: 19).

\section{Kutipan 07}

Lama-lama mereka mengenali para pendatang baru itu. Nipong namanya. ... (Kartadinata, 2017: 20).

Kutipan 06 dan 07 menggambarkan saat-saat pemerintah Jepang menyerahkan kekuasaan kepada Belanda. Hal ini sesuai dengan yang diungkapkan Sulasman (2013:4 31) bahwa Letnan Jenderal H. Ter Poorten, Panglima Angkatan Darat Hindia Belanda, memerintahkan Gubernur Jenderal Tjarda van Starkenborgh Stachouwer agar menolak permintaan Jepang. Hal ini menyebabkan Jenderal Hitoshi Imamura mengeluarkan ultimatum bahwa Kota Bandung akan dihancurkan jika sampai tanggal 8 Maret 1942 pukul 10.00 pembesar Belanda belum pergi ke Kalijati, Subang. Untuk membuktikan ultimatum tersebut, Angkatan Udara Jepang unjuk kekuatan dengan menjatuhkan bom di perempatan Regentsweg Dalem Kaum yang mengakibatkan banyak korban tewas. Akhirnya, Panglima Tentara Hindia Belanda Letnan Jenderal H. Ter Poorten, Gubernur Jenderal Tjarda van Stachouver, beberapa pejabat tinggi militer, dan seorang penerjemah berangkat ke Kalijati, Subang. 
Selanjutnya menurut Notosusanto (1979: 27), rombongan petinggi Belanda tersebut bertemu dengan Jenderal Imamura di Subang. Perundingan tersebut menghasilkan kesepakatan bahwa Angkatan Perang Belanda menyerah tanpa syarat kepada Jepang. Hal ini berarti pada tanggal 8 Maret 1942, pemerintahan Hindia Belanda berakhir di Indonesia. Hal ini sesuai dengan yang diungkapkan Sofianto (dalam Rahma dkk, 2020: 42) bahwa dalam perundingan di Kalijati, Subang, tanggal 8 Maret 1942, Belanda menyerah tanpa syarat.

Peristiwa sejarah selanjutnya yang tergambar dalam novel Hinomaru adalah adanya eksploitasi seksual terhadap perempuan-perempuan Sunda oleh tentara Jepang. Hal ini terlihat pada alur cerita tokoh utama, Halisah, dan teman-temannya, seperti terlihat pada kutipan berikut.

\section{Kutipan 08}

"Sah, saya tahu, mereka melakukan itu karena mereka telah membayar kita."

Halisah terperangah, "Mereka membayar kita? Saya tidak pernah menerima uang. Kamu pernah menerimanya?"

Astuti menggeleng,"Serdadu membayar kita seharga dua yen sampai tiga yen. Dan perwira membayar kita sampai dua belas yen." (Kartadinata, 2017: 113).

Pada kutipan 08 digambarkan bagaimana tokoh utama dalam novel Hinomaru menjadi korban kekerasan seksual tentara Jepang. Hal ini sesuai dengan yang diungkapkan Rahma, dkk (2020: 37) bahwa dalam masa pendudukannya, Jepang menerapkan beberapa sistem untuk memobilisasi rakyat Indonesia, salah satunya adalah sistem perbudakan seksual militer Jepang yang merupakan mekanisme dengan cara paksa menyediakan perempuan-perempuan sebagai sarana praktik seksual untuk tentara Jepang di semua wilayah pendudukan Jepang di Indonesia. Kekaisaran Jepang menamai perempuan-perempuan dalam sistem ini dengan sebutan Jugun Ianfu.

Menurut Suyono (2004: 281) tentara Jepang bisa mengumpulkan gadis-gadis pribumi dilakukan dengan berbagai tipu daya. Para gadis tersebut dijanjikan untuk sekolah perawat dan dikirim ke Jepang. Namun, kenyataannya mereka dijadikan Jugun Ianfu. Setelah perang berakhir, banyak diantaranya yang melakukan bunuh diri karena merasa malu untuk kembali ke kampung halamannya. Perekrutan gadis-gadis pribumi untuk dijadikan Jugun Ianfu juga tergambar dalam kutipan novel berikut.

\section{Kutipan 09}

Solehati masih terbengong melihat tingkah Halisah, "Apa? Jadi juru rawat, Geulis? Naon maksadna? Emak tidak mengerti." Solehati meletakkan piring berisi bubuy ubi. "Iya, jadi juru rawat, dan Isah mau disekolahkan ke negara orang-orang Nipong, Mak!"

\section{B. Representasi Budaya dalam Novel Hinomaru}

Sisi budaya yang tergambar pada novel Hinomaru didominasi oleh budaya Sunda. Hal ini sesuai dengan latar tempat novel yang dipilih, yakni Ciwidey, Jawa Barat. Aspek budaya tersebut meliputi penggunaan partikel, kata-kata, kata sapaan, kiasan, tembang, permainan tradisional, dan puisi Sunda (sisindiran). Penggunaan partikel khas sunda terlihat pada kata atuh, tea, mah halaman 31 berikut.

\section{Kutipan 10}

“... Pasti atuh. Karnaya tea...” Ujang menjentikkan ibu jarinya.

"Sayang, Isah teh agak susah didekati."

"Alah, kalau pake ini mah, gak ada yang susah..."

Menurut Muller Gotama (dalam Bulan, 2018: 12), teh berfungsi untuk menjadi penanda frasa yang berisi informasi yang telah diketahui. Hal ini bertujuan untuk mempertegas informasi tersebut. Sementara itu, tea menurut Hardjadibrata (dalam Bulan, 2018: 12) dikategorikan sebagai penanda tentu atau penanda kepastian. Adapun mah menurut Gotama (dalam Bulan, 2018: 13) digunakan untuk mengekspresikan perbandingan. Partikel mah digunakan untuk menandai fokus informasi baru dalam sebuah percakapan atau membandingkan informasi yang ada. 
Selain partikel, terdapat pula penggunaan kata-kata dalam bahasa Sunda seperti kata panggeulisna, bentangna, dan belegug. Hal ini terlihat pada kutipan 11 berikut.

\section{Kutipan 11}

"Memang beda atuh. Isah mah pan panggeulisna di kampung ini mah. Dia mah bentangna!"

Unsur budaya lain yang merupakan bagian dari kebahasaan terlihat pada penggunaan nama panggilan/sapaan khas sunda seperti panggilan nyai, ujang/jang, nung, dan geulis. Hal ini tergambar pada kutipan halaman 29 - 30 berikut.

\section{Kutipan 12}

"Kita ini hanya perempuan, Nung. Mau apa lagi? Kita dilahirkan hanya untuk menjadi istri. Istri yang harus nurut kepada suami. Istri yang harus mengurus dapur, sumur, kasur. Kamu mau dilamar Jang Karnaya, itu sudah beruntung. Mana ada perempuan yang seberuntung kamu, Geulis."

Nung dan geulis merupakan panggilan penuh kasih sayang untuk anak perempuan. Sementara, jang digunakan untuk memanggil sekaligus bentuk penghormatan kepada anak lakilaki.

Selain panggilan khas Sunda, unsur budaya lain yang terlihat pada kutipan 12 di atas adalah aturan untuk para perempuan Sunda yang hanya diperbolehkan beraktivitas mengurus dapur, sumur, dan kasur. Keterbatasan pendidikan kaum perempuan pada waktu itu diungkapkan oleh Suhendra (2014: 107) bahwa istilah teu kudu nyakola luhur, da awewe mah moal jauh ti urusan dapur, sumur, jeung kasur 'tidak perlu sekolah tinggi karena perempuan tidak jauh dari urusan dapur (memasak), sumur (mencuci), dan kasur (hubungan suami istri)' menunjukkan bahwa perempuan dibentuk sebagai entitas domestic dalam budaya Sunda. Sementara itu, sisi sosial perempuan, terutama masalah pendidikan, menjadi termarginalkan.

Kiasan dapur, sumur, jeung kasur yang ditujukan untuk batas lingkup perempuan Sunda juga menunjukkan tradisi bahwa perempuan tidak perlu bersekolah. Yang mendapatkan hak untuk bersekolah hanya laki-laki saja. Hal ini terlihat pada kutipan 13 berikut.

\section{Kutipan 13}

$\cdots$

Matanya menyapu dua bola bening anaknya yang tengah kebingungan. Hatinya berbisik: Andaikan kamu sekolah, Nak, tentu emakmu yang bodoh ini tak perlu bersusah payah mencarikan jawaban untuk pertanaan itu. Gurumu pasti lebih bisa menjawabnya (Kartadinata, 2017: 2).

Gambaran pendidikan yang terlihat pada kutipan di atas sesuai dengan pernyataan yang diungkapkan Amar (2017: 109) bahwa pada masa itu, masyarakat yang bisa mendapatkan pendidikan hanya kaum laki-laki saja. Sementara kaum perempuan, belum sepenuhnya bisa mengenyam pendidikan. Hal ini disebabkan oleh adanya tatanan dan tradisi yang membelenggu.

Kiasan lainnya yang terdapat dalam novel Hinomaru menunjukkan sifat masyarakat Sunda yang mengutamakan kebersamaan seperti pada pada kutipan berikut.

\section{Kutipan 14}

... mereka makin jauh dijangkau. Sebuah filsafat lama orang sunda, bengkung ngariung bengkok ngaronyok melesap sudah ke angkasa. Bayang-bayang kerinduan pun kian lekat, kental, menggila. ... (Kartadinata, 2017: 73).

Penggunaan kiasan bengkung ngariung bengkok ngaronyok merupakan bentuk singkat dari kiasan bengkung ngariung bengkok ngaronyok, asal di bali geusan ngajadi. Menurut Muhsin (2011: 56) kiasan tersebut merupakan sikap hidup orang Sunda yang merasa tidak bisa terpisah dari saudara dan keluarga. Keterikatan batin orang Sunda terhadap kampung halamannya sangat tinggi. Hidup atau mati, kaya atau miskin, selama masih bisa berkumpul dengan sanak saudara di tempat kelahirannya menjadi keinginan setiap anggota keluarga di 
daerah sunda. Berdekatan dengan sanak saudara dianggap lebih penting dari apapun. Apabila meninggal dunia, orang Sunda lebih mengharapkan dikuburkan di tempat kelahirannya.

Unsur budaya selanjutnya yang terdapat dalam novel Hinomaru terlihat dalam bentuk pantun, seperti pada kutipan halaman 21 berikut.

\section{Kutipan 15}

"Ngala lele make parik, dipasakna eujeung hurang, anu bule geus baralik, ayeuna datang si tarang herang..."

Bentuk pantun pada kutipan di atas termasuk ke dalam puisi lama. Dalam sastra Sunda disebut dengan sisindiran. Menurut Masduki (2013:2) sisindiran merupakan salah satu puisi lama yang terbentuk dari 2 baris sampiran dan 2 baris isi. Sisindirian digunakan untuk menggambarkan perasaan, keadaan lingkungan, dan situasi masyarakat, dan lain-lain. Sisindiran ini sangat memasyarakat karena dapat disampaikan dalam berbagai situasi, baik santai maupun formal.

Pada novel Hinomaru, terdapat juga gambaran permainan tradisional yang dimainkan anak-anak. Permainan tradisional yang dimaksud adalah perepet jengkol yang sudah diubah sedikit kata-katanya oleh penulis novel karena alasan kesopanan. Kutipan yang menunjukkan hal tersebut terlihat pada halaman 13 .

\section{Kutipan 16}

... Ada juga gabungan beberapa anak perempuan dan laki-laki yang sedang bermain perepet jengkol. Terdengar nyanyian khas permainan itu. "Perepet jengkol jajahean, kadempet kohkol jejeretean..."

Sunaryo dkk (2020) mengungkapkan bahwa perepet jengkol adalah permainan tradisional Sunda. Permainan ini dapat dilakukan oleh beberapa orang yang saling memegang tangan dan membelakangi temannya masing-masing. Kaki kanan setiap orang saling dibelitkan, lalu meloncat-loncat, memutar, dan bertepuk tangan. Hal ini dilakukan untuk menguji orangorang yang terlibat dalam permainan tersebut supaya tidak jatuh.

Dalam budaya Sunda terdapat tradisi mepende 'mengeloni'. Ketika mepende, nyanyian yang biasa digunakan adalah ayun ambing. Hal ini sesuai dengan yang diungkapkan Yani (2020: 162) bahwa tembang ayun ambing digunakan masyarakat Sunda pada umumnya ketika akan menidurkan anak (mepende). Dalam novel Hinomaru tradisi mepende terlihat pada kutipan berikut.

\section{Kutipan 17}

Ayun-ayun ambing, diayun-ayun ku samping

Ayun-ayun ambing, diayun-ayun ku samping

Alunan itu masih terasa, ketika bayi montok Atikah menempel di dadanya hangat. ..." (Kartadinata, 2017: 70).

\section{Representasi Ekonomi dalam Novel Hinomaru}

Keadaan ekonomi yang tergambar pada novel Hinomaru lebih didominasi oleh kemiskinan dan kelaparan yang disebabkan oleh adanya kewajiban membayar pajak terhadap penjajah. Selain itu, digambarkan pula jenis pekerjaan penduduk pada umumnya. Hal ini terlihat dari perjalanan hidup tokoh utama ketika masih tinggal dengan ibunya. Representasi ekonomi dalam novel Hinomaru tersebut dapat terlihat pada beberapa kutipan berikut.

\section{Kutipan 18}

... Dulu, juragan berkulit putih sering lewat, diikuti pengiring dengan pakaian bagus dan langkah sombong. Para pegawai desa juga sering melintas di jalan itu. Terkadang mereka memikul beban makanan dan hasil panen atau tagihan pajak (Kartadinata, 2017:4).

Pada kutipan di atas digambarkan adanya kewajiban masyarakat untuk membayar pajak berupa makanan dan hasil panen terhadap belanda. Hal ini diungkapkan oleh Pusponegoro (1976: 1) bahwa ketika penjajahan Belanda, sistem tanam paksa diterapkan untuk memacu produksi alam. Selanjutnya, pajak harus dibayarkan oleh pribumi dalam bentuk hasil bumi agar 
bisa diekspor. Sebanyak 20 persen tanah desa harus disisihkan untuk ditanami kopi, tebu, dan nila.

Keadaan kesulitan ekonomi juga terlihat pada jaman Jepang. Tidak jauh berbeda dengan jaman penjajahan Belanda karena sama-sama ada kewajiban untuk memberikan hasil panen kepada penjajah. Keadaan ekonomi masyarakat yang sulit pada jaman Jepang terlihat pada halaman 22 novel tersebut seperti terlihat pada kutipan berikut.

\section{Kutipan 19}

"Kita makan lalapan. Di halaman masih banyak singkong dan daunnya. Terasi kita punya, tinggal mencari rumput janggut, antanan, kamanilan, jotang, atau daun senggang."

"Kenapa jadi begini, Mak?'

"Kita harus sabar, Geulis."

Pada kutipan di atas digambarkan keadaan masyarakat yang susah mendapatkan makanan sehingga harus mengkonsumsi daun-daunan. Keadaan seperti ini juga tergambar pada kutipan berikut.

\section{Kutipan 20}

Beberapa hari berikutnya, kedatangan serdadu itu mulai mengubah kehidupan. Orang yang lalu lalang dari dan ke pasar, sering mengeluhkan harga beras yang mulai mahal. Tidak heran, para penduduk mencari pengganti nasi di tegalan. Mereka beramai-ramai mencari singkong atau ubi jalar. Pemilik kebun yang luas, tidak segan-segan membagi kepada yang tidak punya. Yang penting seluruh tetangga, atau saudara bisa makan. Sementara hasil bumi berupa padi, terus diminta oleh tentara Nipong. (Kartadinata, 2017: 25).

Kondisi ekonomi masyarakat yang tergambar Dari kedua kutipan di atas sesuai dengan gambaran yang disampaikan Muljana (2008: 15) bahwa para petani dipaksa untuk menjual padi kepada pemerintah balatentara Jepang dengan harga sangat murah. Para petani tidak ada yang bisa lolos dari perdagangan yang mencekik tersebut. Hal serupa juga disampaikan oleh Sulasman $(2013,440$ - 441) yang menyebutkan bahwa terdapat kebijakan wajib serah padi kepada Jepang sehingga kelaparan terjadi dimana-mana. Penduduk banyak yang tidak bisa lagi makan nasi. Paling bagus, mereka makan nasi tetapi dicampur dengan pisang, atau bahkan hanya bisa makan bonggol pisang. Para ibu ramai-ramai mencari hui (ubi) atau pisang setiap pagi di kebun.

\section{KESIMPULAN}

Berdasarkan hasil pembahasan dapat disimpulkan sebagai berikut. (1) representasi peristiwa sejarah yang terdapat pada novel Hinomaru karya Iis W. Kartadinata digambarkan dalam kewajiban masyarakat pribumi menghormati Dewi Amaterasu dan Kaisar Jepang, mundurnya Belanda oleh Jepang pada tanggal 8 Maret 1942, dan adanya eksploitasi seksual terhadap perempuan-perempuan Sunda oleh tentara Jepang. (2) Representasi budaya dalam novel Hinomaru terlihat dari penggunaan partikel, kata-kata, panggilan, kiasan, tembang, pantun, dan permainan tradisional Sunda. (3) Representasi ekonomi dalam novel Hinomaru mengenai jenis pekerjaan sebagian besar penduduk, kemiskinan, dan kelaparan yang diderita karena adanya kewajiban membayar pajak terhadap penjajah serta adanya sistem tanam paksa.

\section{DAFTAR PUSTAKA}

Amar, Syahrul. (2017). Perjuangan Gender dalam Kajian Sejarah Wanita Indonesia pada Abad XIX. Fajar Historia. 3 (2), 105 - 119, from DOI: 10.29408/fhs.vli2.587.

Ardhianti, Mimas. (2016). Kajian New Historicism Novel Hatta: Aku Datang karena Sejarah Karya Sergius Sutanto. Buana Sastra. 3 (1), 1 - 10, from http://jurnal.unipasby.ac.id/index.php/bastra/article/view/652/519.

Budianta, M. (2006). Budaya, Sejarah, dan Pasar: New Historicism dalam Perkembangan Kritik Sastra. Susastra Jurnal Ilmu Sastra dan Budaya. 2 (3), 1 - 19, from SJIS-2-3-2006-1. 
Bulan, D. R. (2018). Partikel Penegas Bahasa Sunda Teh, Tea, dan Mah. Metamorfosis, Jurnal Bahasa, Sastra Indonesia dan Pengajarannya. 11 (1), 10 - 14, from http://ejournal.unibba.ac.id/index.php/metamorfosis/article/viey/24.

Kartadinata, Iis W. (2017). Hinomaru. Bandung: Situseni.

Lawanda, Ike Iswary. (2008). Interpretasi antara Amaterasu Oomikami dan Lingkungan Jepang. Makara, Sosial Humaniora. 12 (2), 56 - 64, from DOI: https://10.7454/mssh.v12i2.148.

Masduki, Aam. (2013). Puisi Sisindiran Bahasa Sunda di Kabupaten Bandung (Kajian Isi dan Fungsi). Patanjala. 5 (2), 356 - 369, from doi:10.30959/patanjala.v5i2.148.

Muhsin Z., Mumuh dkk. (2011). Kajian Identifikasi Permasalahan Kebudayaan Sunda Masa Lalu, Masa Kini, dan Masa yang Akan Datang. Fakultas Sastra Universitas Padjajaran. From http://pustaka.unpad.ac.id/wp-content/uploads/2013/10/KAJIAN-IDENTIFIKASIPERMASALAHAN-KEBUDAYAAN-SUNDA.pdf.

Mumtaz, Fairuzul. (2014). Membongkar Kubur Sugiarti Siswadi (Sebuah Kajian New Historicism). (Tesis, Universitas Sanata Dharma). Diakses dari

https://repository.usd.ac.id/124/2/096322014full.pdf.

Muljana, Slamet. (2008). Kesadaran Nasional dari Kolonialisme sampai Kemerdekaan Jilid II. Salatiga: LKis.

Notosusanto, Nugroho. (1979). Tentara PETA pada Jaman Pendudukan Jepang di Indonesia. Jakarta: Gramedia.

Nurgiyantoro, Burhan. (2007). Teori Pengkajian Fiksi. Yogyakarta: Gadjah Mada University Press.

Oktorino, N. (2013). Konfik Bersejarah - Runtuhnya Hindia Belanda. Jakarta: Gramedia.

Poesponegoro, Marwati Djoened. (1976). Sejarah Nasional Indonesia V. Jakarta: Balai Pustaka.

Rahma, A. D., Suswandari, \& Naredi, H. (2020). Jugun Ianfu: Kekerasan Seksual terhadap Perempuan pada Masa Pendudukan Jepang di Jawa Barat Tahun 1942 - 1945. Chronologia: Journal of History Education. 1 (3), 36 - 49, from http://dx.doi.org/10.

Ratna, Nyoman Kutha. (2008). Postkolonialisme Indonesia Relevansi Sastra. Yogyakarta: Pustaka Pelajar.

Ratna, Nyoman Kutha. (2009). Stilistika: Kajian Puitika, Bahasa, Sastra, dan Budaya. Yogyakarta: Pustaka Pelajar.

Ricklefs, M. C. (2008). Sejarah Indonesia Modern 1200 - 2004 (diterjemahkan dari A History of Modern Indonesia Since c. 1200 Fourth Edition). Jakarta: Serambi Ilmu Semesta.

Suhendra, Ahmad. (2014). Nilai Kearifan Lokal dalam Hadis: Studi atas Hadis Perempuan Menstruasi. Musawa. 13 (2), 99 - 109, from https://doi.org/10.14421/musawa.2014.132.99-110.

Sulasman. (2013). Panasnya Matahari Terbit Derita Rakyat Sukabumi pada Masa Pendudukan Jepang 1942 - 1945. Patanjala, Jurnal Penelitian Sejarah dan Budaya. 5 (3), 431 448, from DOI:10.30959/patanjala.v5i3.97.

Sunaryo, Oyo dkk. (2020). Gerak Relationship pada Permainan Anak Sunda sebagai Sumber Penciptaan Komposisi Tari Anak. Jurnal Obsesi: Jurnal Pendidikan Anak Usia Dini. 4 (2), 1076 - 1086, from DOI:10.31004/obsesi.v4i2.499.

Suyono, R. P. (2004). Seks dan Kekerasan pada Zaman Kolonial. Jakarta: Grasindo.

Wellek, R. dan Warren, A. (1955). Teori Kesusastraan. Jakarta: PT. Grasindo.

Yani, Zulkarnain. (2020). Tradisi Mepende dan Nilai-nilai Pendidikan Agama: Studi Kasus di Masyarakat Ujungberung - Kota Bandung. Proceeding of Seminar International Literature Nusantara. 2 (1), 159 - 178, from doi: http://dx.doi.org/10.32678/silin.v2il.4211. 